\title{
Muscular dystrophy with arrhythmia caused by loss-of-function mutations in BVES
}

Willem De Ridder, MD,* Isabelle Nelson, PhD, * Bob Asselbergh, PhD, Boel De Paepe, PhD, Maud Beuvin, MSc, Rabah Ben Yaou, MD, Cécile Masson, MSc, Anne Boland, PhD, Jean-François Deleuze, PhD,

Thierry Maisonobe, MD, Bruno Eymard, MD, PhD, Sofie Symoens, PhD, Roland Schindler, PhD,

Thomas Brand, PhD, Katherine Johnson, PhD, Ana Töpf, PhD, Volker Straub, MD, PhD,

Peter De Jonghe, MD, PhD, Jan L. De Bleecker, MD, PhD, Gisèle Bonne, PhD, $†$ and Jonathan Baets, MD, PhD $\dagger$

Neurol Genet 2019;5:e321. doi:10.1212/NXG.0000000000000321

\section{Abstract}

\section{Objective}

To study the genetic and phenotypic spectrum of patients harboring recessive mutations in BVES.

\section{Methods}

We performed whole-exome sequencing in a multicenter cohort of 1929 patients with a suspected hereditary myopathy, showing unexplained limb-girdle muscular weakness and/or elevated creatine kinase levels. Immunohistochemistry and mRNA experiments on patients' skeletal muscle tissue were performed to study the pathogenicity of identified loss-of-function (LOF) variants in BVES.

\section{Results}

We identified 4 individuals from 3 families harboring homozygous LOF variants in BVES, the gene that encodes for Popeye domain containing protein 1 (POPDC1). Patients showed skeletal muscle involvement and cardiac conduction abnormalities of varying nature and severity, but all exhibited at least subclinical signs of both skeletal muscle and cardiac disease. All identified mutations lead to a partial or complete loss of function of BVES through nonsensemediated decay or through functional changes to the POPDC1 protein.

\section{Conclusions}

We report the identification of homozygous LOF mutations in BVES, causal in a young adultonset myopathy with concomitant cardiac conduction disorders in the absence of structural heart disease. These findings underline the role of POPDC1, and by extension, other members of this protein family, in striated muscle physiology and disease. This disorder appears to have a low prevalence, although it is probably underdiagnosed because of its striking phenotypic variability and often subtle yet clinically relevant manifestations, particularly concerning the cardiac conduction abnormalities.

\author{
Correspondence \\ Dr. Baets \\ jonathan.baets@uantwerpen.vib.be
}

*These authors contributed equally to the manuscript as first authors.

tThese authors contributed equally to the manuscript as last authors.

From the Neurogenetics Group (W.D.R., P.D.J., J.B.), University of Antwerp; the Laboratory of Neuromuscular Pathology (W.D.R., P.D.J., J.B.), Institute Born- Bunge, University of Antwerp; the Neuromuscular Reference Centre (W.D.R., P.D.J., J.B.), Department of Neurology, Antwerp University Hospital, Belgium; Sorbonne Université (I.N., M.B., R.B.Y., G.B.), INSERM U974, Center of Research in Myology, Institute of Myology, G.H. Pitié-Salpêtrière Paris, France; Histology and Cellular Imaging (B.A.), Neuromics Support Facility, VIB-UAntwerp Center for Molecular Neurology, University of Antwerp; Laboratory for Neuropathology (B.D.P., J.D.B.), Division of Neurology, Ghent University Hospital, Belgium; AP-HP, Centre de Référence de Pathologie Neuromusculaire Nord/Est/Ile-deFrance (R.B.Y., B.E.), G.H. Pitié-Salpêtrière, Bioinformatics Unit (C.M.), Necker Hospital, AP-HP, and University Paris Descartes, ; Centre National de Recherche en Génomique Humaine (CNRGH) (A.B., J.F.D.), Institut de Biologie François Jacob, CEA, Université Paris-Saclay, Evry; Laboratoire de Neuropathologie (T.M.), G.H. Pitié-Salpêtrière, Paris, France; Center for Medical Genetics (S.S.), Ghent University Hospital, Belgium; Developmental Dynamics, Imperial Centre for Experimental and Translational Medicine (R.S., T.B.), Imperial College London; John Walton Muscular Dystrophy Research Centre (K.J., A.T., V.S.), MRC Centre for Neuromuscular Diseases, Institute of Genetic Medicine, Newcastle University, Newcastle upon Tyne, United Kingdom.

Funding information and disclosures are provided at the end of the article. Full disclosure form information provided by the authors is available with the full text of this article at Neurology.org/NG.

The Article Processing Charge was funded by the authors.

This is an open access article distributed under the terms of the Creative Commons Attribution-NonCommercial-NoDerivatives License 4.0 (CC BY-NC-ND), which permits downloading and sharing the work provided it is properly cited. The work cannot be changed in any way or used commercially without permission from the journal. 


\section{Glossary}

AV = atrioventricular $\mathbf{C A D D}=$ Combined Annotation-Dependent Depletion; $\mathbf{C K}=$ creatine kinase $; \mathbf{E P S}=$ electrophysiology study; EPS = electrophysiology study; ExAC = Exome Aggregation Consortium; IHC = immunohistochemical; KI = knock-in; LGMD = limb-girdle muscular dystrophy; LOF = loss of function; NMD = nonsense-mediated mRNA decay; PCCD = progressive cardiac conduction disorder; SND = sinus node dysfunction; WES = whole-exome sequencing.

Limb-girdle muscular dystrophies (LGMDs) comprise a phenotypically and genetically heterogeneous group of autosomally inherited myopathies characterized by progressive proximal muscle weakness. ${ }^{1}$ Cardiac involvement is common in LGMDs, ${ }^{2}$ and practice guidelines recommend referring patients for cardiac assessment. ${ }^{3}$ Hereditary cardiac conduction disorders without structural cardiac disease are rare, but an increasing number of culprit genes are being identified. $^{4}$

Previously, a homozygous missense mutation (p.Ser201Phe) in the blood vessel epicardial substance (BVES) gene has been identified in 3 individuals from a single family, the eldest presenting with an overt LGMD phenotype and all 3 showing elevated creatine kinase (CK) levels and a seconddegree atrioventricular $(\mathrm{AV})$ block. $^{5}$ The disease was originally classified as LGMD2X (OMIM \#616812). BVES encodes for a 360 amino acid protein also known as POPDC1, part of the Popeye domain containing (POPDC) family of proteins, which are cyclic $3^{\prime}, 5^{\prime}$-adenosine monophosphate (cAMP)-binding transmembrane proteins that are abundantly expressed in striated muscle. ${ }^{6}$ In patients' muscle, a marked reduction was observed in the membrane localization of POPDC 1 and POPDC2. ${ }^{5}$ In zebrafish popdc1 morphants and popdc1 ${ }^{\text {p.Ser191Phe }}$ knock-in (KI) mutants, skeletal muscle abnormalities and AV conduction blocks have been noted. ${ }^{5}$ In addition, previously reported homozygous Popdc1 null mutant mice showed delayed skeletal muscle regeneration and an age-dependent stress-induced sinus node dysfunction (SND), ${ }^{7,8}$
Here, we present 4 individuals from 3 families harboring homozygous loss-of-function (LOF) mutations in BVES. We show that the skeletal muscle and cardiac involvement resulting from these BVES mutations is highly variable and emphasizes the relevance of $B V E S$ mutations with regard to hereditary cardiac conduction disorders.

\section{Methods}

\section{Standard protocol approvals, registrations, and patient consents}

Ethical approval was granted by the relevant local ethical committees of the participating centers. All patients provided their written consent for participation in the study.

\section{Patients and clinical evaluation}

We studied 4 patients harboring rare variants in BVES, identified by whole-exome sequencing (WES) of a cohort of 1929 unsolved cases with limb-girdle muscular weakness and/ or an elevated CK level, established through an international collaboration between different clinical and genetic centers: the MYO-SEQ project, the Myocapture project, and the Center for Medical Genetics of the Ghent University Hospital. Patients 1 and 2 (family A) are siblings of consanguineous parents (figure 1). Patient 3 (family B) and patient 4 (family C) are isolated cases, with the maternal grandfather and paternal grandmother of patient 4 being first cousins.

Medical history taking and physical examination were focused on neuromuscular and cardiac symptoms and signs. Muscle

Figure 1 Segregation analysis of the 3 identified BVES mutations

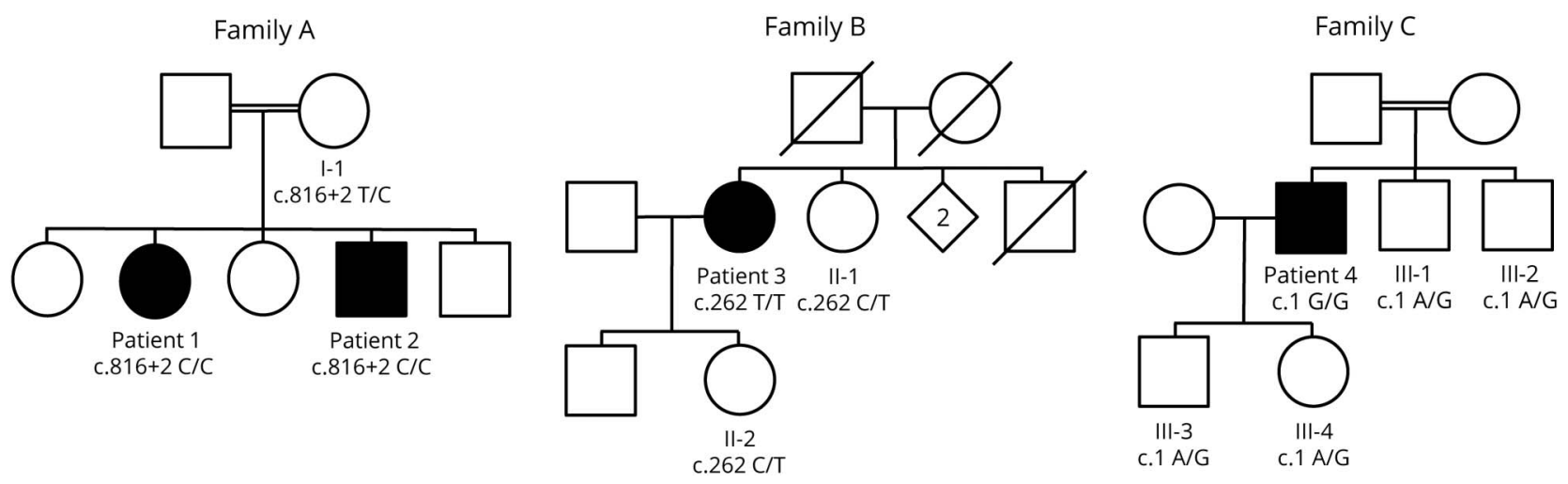

Pedigrees of families A, B, and C are shown. Unaffected family members for whom DNA was available for segregation analysis of the BVES variants in the respective families, I-1, II-1, II-2, III-1, III-2, III-3, and III-4, were heterozygous for the respective variants. 
strength was evaluated according to the Medical Research Council scale. Cardiac function was assessed by ECG, Holter monitoring, and echocardiography in all patients. In addition, arm ergometer stress testing was performed in patient 3 and bicycle ergometer stress testing and a cardiac electrophysiology study (EPS) in patient 2.

\section{Muscle MRI}

Muscle MRI studies were performed for patients 1, 2, and 3 on 1.5-T MRI platforms at the respective centers. Cross sections at the pelvic, thigh, and calf levels were assessed on axial T1-weighted images to evaluate patterns of muscle involvement. Fatty replacement of muscle was graded according to the Mercuri scale. ${ }^{9}$

\section{Analysis of WES data}

For family A, WES was performed by the CNRGH on DNA samples from patients 1 and 2 and their mother. Variants were annotated and filtered using an in-house-developed software system (PolyWeb). ${ }^{10}$ WES data of patient 3 were processed by the Genomics Platform at the Broad Institute MIT and Harvard (Boston, MA) and analyzed by the team at the John Walton Muscular Dystrophy Research Centre, Newcastle University, as described previously. ${ }^{11}$ For patient 4 , WES was performed using the SureSelect XT Human All Exon V6 enrichment kit (Agilent Technologies), followed by paired-end sequencing $(2 \times 150 \mathrm{bp})$ on the HiSeq3000 sequencer (Illumina). Reads were mapped, and variants were called and annotated with the $\mathrm{BCBio}$ pipeline.

BVES (reference sequence: NM_001199563) was analyzed for biologically relevant variants. Population frequencies were estimated using Exome Aggregation Consortium (ExAC), ${ }^{12}$ last accessed in August 2018. MutationTaster ${ }^{13}$ and the Combined Annotation Dependent Depletion (CADD) ${ }^{14}$ tool (version v1.3) were used as in silico prediction algorithms to predict the pathogenicity of the identified variants. Variants with CADD scores $>20$ represent the $1 \%$ highest ranked variants genome wide with regard to potential deleteriousness. In silico splice site predictions were obtained using Alamut Batch Software v.2.8 (Interactive Biosoftware). Variants were validated by Sanger sequencing, and segregation studies were performed with available DNA samples.

\section{Muscle biopsies}

Muscle biopsies of quadriceps or deltoid muscle were obtained for patients 2, 3, and 4 and analyzed following standard histologic and immunohistochemical (IHC) procedures. Standard IHC stainings, including those for dystrophin, $\alpha$-, $\beta$-, and $\gamma$-sarcoglycans, $\alpha$ - and $\beta$-dystroglycan, caveolin 3, and telethonin, were evaluated. In addition, IHC stainings were performed for POPDC1 and POPDC2. Frozen 10- $\mu \mathrm{m}$ sections of skeletal muscle biopsies of patients and 2 controls were mounted on Superfrost Plus glass slides (Thermo Fisher Scientific) and used for IHC using the following primary antibodies as described ${ }^{5}$ : anti-POPDC1 (HPA014788, SigmaAldrich) and anti-POPDC2 (HPA024255, Sigma-Aldrich), combined with anti- $\alpha$-sarcoglycan (SGCA) (NCL-a-sarc,
Leica), for membrane counterstaining. The following secondary antibodies were used for detection of the signal: Alexa Fluor 488-conjugated goat anti-rabbit (A11034, Life Technologies) and CY3labeled goat antimouse (115-166-071, Jackson ImmunoResearch).

\section{Microscopy and image analysis}

Images were acquired with a Zeiss LSM700 laser scanning confocal microscope using a 20x/0.8 Plan Apochromat objective. To avoid crosstalk between fluorescence channels, line-by-line sequential scanning was used. All images (16-bit, $512 \times 512$ pixels, $417 \mathrm{~nm} \times 417 \mathrm{~nm}$ per pixel) were taken with identical excitation and detection settings to allow comparison of fluorescence intensities. For each sample, 5 images were acquired at random positions. Intensities at the sarcolemma were quantified using the Fiji distribution of ImageJ. ${ }^{15,16}$ Raw image files (LSM5) were loaded in Fiji, and background intensity levels were corrected by subtracting the mean intensity of the Gaussian blurred image (sigma $=20$ pixels) from the original image. On each image, 6 random membrane segments were delineated (average line length per segment $>50 \mu \mathrm{m}$ ) using the segmented line tool on the sarcolemma channel and were stored as ImageJ ROI files. Intensities in both channels (POPDC1/POPDC2 and SGCA) were quantified as mean intensities of these lines, set at a line width of 5 pixels $(2 \mu \mathrm{m})$. The analysis procedure was used as an ImageJ macro, measuring all images in batch.

\section{mRNA studies}

Total RNA was extracted from muscle biopsies (controls and patients) using standard methods (TRIzol). First-strand cDNA was synthesized using the SuperScript III FirstStrand Synthesis System (Invitrogen-Thermo Fisher Scientific) with Oligo-dTs. The obtained cDNA was used for Sanger sequencing and quantitative PCR (qPCR) experiments with SYBR green I dye incorporation (LightCycler 480 System; Roche, Basel, Switzerland). The average Ct value obtained with multiple BVES primers (figure $2 \mathrm{~A}$ ) was normalized against the housekeeping gene RPLP0; then, fold changes in mRNA levels were calculated relative to the control sample.

Experiments were performed in triplicate. All primer sequences are available upon request.

Data analysis was performed with qBase + (Version 3.1; Biogazelle, Zwijnaarde, Belgium). Data are presented using GraphPad Prism (GraphPad Software, La Jolla, CA) as mean values with standard error of the mean. Data were analyzed using the unpaired $t$ test. $p<0.05$ was considered statistically significant.

\section{Data availability statement}

Anonymized data will be shared by request from any qualified investigator, only for purposes of replicating procedures and results. 


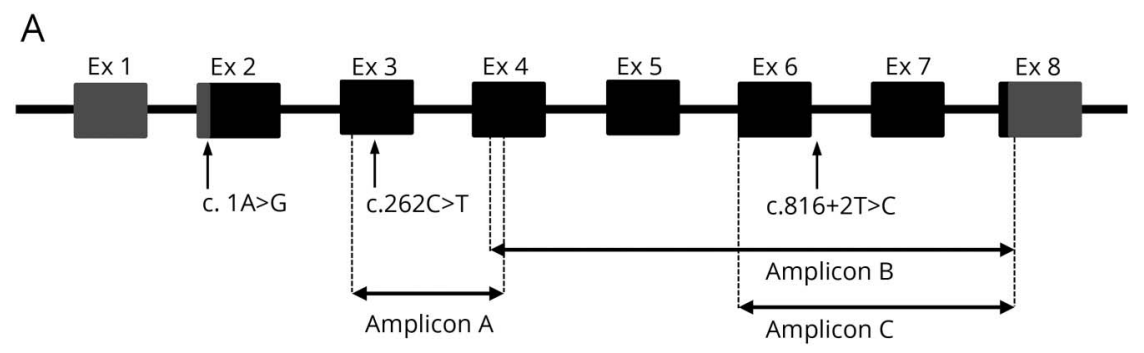

B
C1 P2
C1 P2
C1 P2

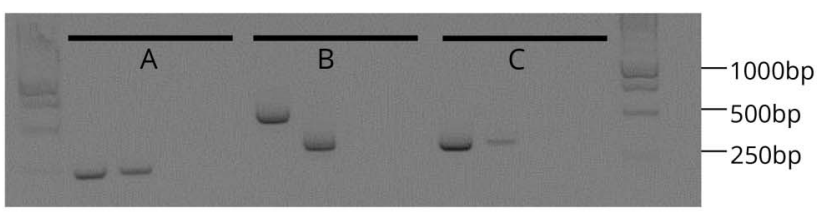

\section{Amplicon A}

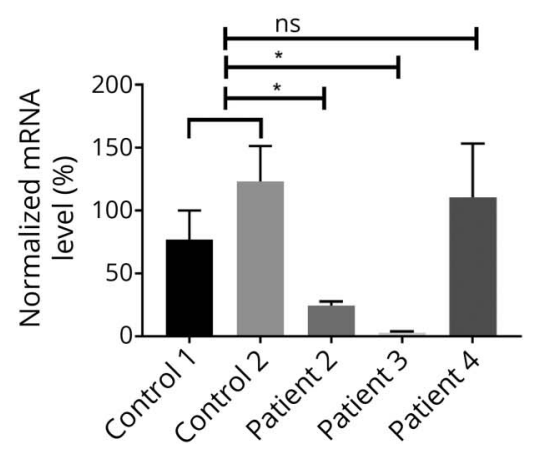

D. Amplicon C

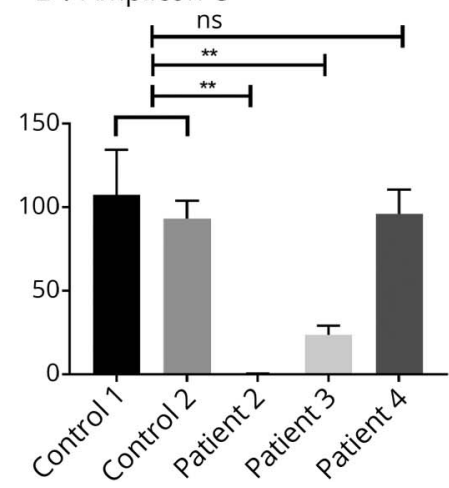

(A) BVES mRNA transcript variant C (NM 001199563) contains 8 exons, of which 7 coding. Transcript length is 5,567 base pairs. Untranslated regions are filled in grey, translated in black. The location of the 3 identified variants is marked with an arrow, position of the amplified fragments for quantitative and quantitative PCR experiments with dashed lines. (B) Qualitative PCR: agarose gel of PCR products (amplicons A, B, and C) amplified from CDNA from control (C1) and patient 2 (P2). For every amplicon, the 2 lanes on the right contain mRNA without reverse transcriptase and $\mathrm{H} 2 \mathrm{O}$, respectively. (C and D) BVES quantitative mRNA analysis for amplicons $A$ and $C$, respectively. $B V E S$ mRNA levels were first normalized internally to RPLPO mRNA levels; subsequently, BVES mRNA levels of the patients were normalized (as a percentage) to the mean of the 2 controls. For both amplicons $\mathrm{A}$ and $\mathrm{C}$, there is a significant difference in mRNA levels between both controls and patients 2 and 3 , respectively, which is not the case for patient 4. Error bars: standard error of the mean (SEM). ${ }^{*} p<$ $0.05, * \star p<0.01$, using the unpaired $t$ test. bp $=$ base pair; $\mathrm{Ex}=$ exon.

\section{Results}

\section{Clinical findings and case descriptions}

A summarized overview of the highly variable clinical symptoms is provided in table 1 .

Patients 1 and 2 are affected siblings, among 5, of consanguineous parents (first cousins). Patient 1, a 41-year-old woman, manifested complaints of exercise-induced myalgia and fatigue of the lower limb muscles and breathlessness from age 27 years. No further skeletal muscle signs or symptoms were noted, and clinical neurologic examination was normal. CK levels, repeatedly measured at that time, were elevated in the range of $13003661 \mathrm{IU} / \mathrm{L}$. EMG was normal, and cardiac assessment revealed a first-degree AV block in the absence of structural cardiac disease on echocardiography. Muscle symptoms and cardiac function remained stable during follow-up.

Patient 2, a currently 37-year-old man, was first investigated at age 19 years, presenting with presyncopal episodes and palpitations. During cardiac workup, a first-degree AV block and a transient second-degree Mobitz type $1 \mathrm{AV}$ block were noted on ECG and Holter monitoring, with an echocardiography showing no structural abnormalities. There were no symptoms suggestive of neuromuscular disease, and clinical examination at age 20 years was normal. However, high CK levels (1,074-3,600 IU/L) were measured repeatedly, EMG disclosed myopathic abnormalities, and muscle biopsy showed mild dystrophic changes with normal routine IHC and Western blot studies. Intercurrently, the patient manifested a symptomatic S1 radiculopathy on the right side at age 22 years, with residual weakness and atrophy of the right gastrocnemius and soleus muscles. An EPS at age 27 years confirmed an AV nodal block, with a normal His-ventricular interval and without SND or ventricular hyperexcitability. During follow-up, this patient manifested multiple presyncopal episodes, and the cardiac conduction abnormalities progressed toward a second-degree Mobitz type $2 \mathrm{AV}$ block combined with an incomplete right bundle branch block. A new EPS at age 29 years revealed a combined AV nodal and infrahissian block (His-ventricular interval ranging 55-80 ms), again without SND or hyperexcitability. Pacemaker implantation was advised but refused by the patient. Bicycle ergometer testing performed at age 35 years showed a second-degree Mobitz type $2 \mathrm{AV}$ block during 
Table 1 Phenotypic information for the patients harboring homozygous mutations in BVES

\begin{tabular}{|c|c|c|c|c|}
\hline & Patient 1 & Patient 2 & Patient 3 & Patient 4 \\
\hline Sex & Female & Male & Female & Male \\
\hline Ethnicity & North African & North African & Caucasian (Belgium) & Caucasian (Belgium) \\
\hline BVES variant, cDNA position & $c .816+2 \mathrm{~T}>\mathrm{C}$ & $c .816+2 T>C$ & c. $262 \mathrm{C}>\mathrm{T}$ & c. $1 \mathrm{~A}>\mathrm{G}$ \\
\hline Age at onset, y & 27 & 19 & 35 & 39 \\
\hline Presenting symptoms & Exercise intolerance & $\begin{array}{l}\text { Palpitations, faintness, } \\
\text { and elevated CK }\end{array}$ & Proximal weakness LL & Myalgia and high CK \\
\hline Age at the last examination, $y$ & 41 & 37 & 65 & 44 \\
\hline \multicolumn{5}{|l|}{ Weakness } \\
\hline Proximal UL & No & No & Yes & No \\
\hline Proximal LL & No & No & Yes & No \\
\hline Distal UL & No & No & Yes & No \\
\hline Distal LL & No & No & Yes & No \\
\hline Other & No & Right calf muscles & Periscapular & No \\
\hline Ambulation status & Ambulatory & Ambulatory & Wheelchair use & Ambulatory \\
\hline Serum CK (IU/L) & $1,300-3,661$ & $1,074-5,500$ & 1918 & $3,500-4,000$ \\
\hline EMG (age, y) & Normal (28) & Myopathic (30) & Myopathic (45) & Myopathic (43) \\
\hline Resting ECG & First-degree AV block & First-degree AV block & Normal & Normal \\
\hline Echocardiography & Normal & Normal & Aortic valve stenosis & Normal \\
\hline Holter monitoring & First-degree AV block & $\begin{array}{l}\text { Second-degree AV block } \\
\text { (Mobitz type 2), iRBBB }\end{array}$ & $\begin{array}{l}\text { Nocturnal first-degree AV } \\
\text { block }\end{array}$ & $\begin{array}{l}\text { Nocturnal second-degree } \\
\text { AV block (Mobitz type 2) }\end{array}$ \\
\hline Bicycle/arm ergometer stress testing & NA & $\begin{array}{l}\text { Bicycle ergometer: Mobitz } \\
\text { type } 2 \text { second-degree AV } \\
\text { block during recovery }\end{array}$ & $\begin{array}{l}\text { Arm ergometer: no } \\
\text { increase in the heart rate } \\
\text { during the test; borderline } \\
\text { first-degree AV block }\end{array}$ & NA \\
\hline Biopsy (age, y) & NA & Myopathic (21) & Myopathic (45) & Myopathic (43) \\
\hline Biopsied muscle & NA & Left deltoid & Quadriceps & Quadriceps \\
\hline
\end{tabular}

Abbreviations: $\mathrm{CK}=$ creatine kinase; $\mathrm{UL}=$ upper limb; $\mathrm{LL}=$ lower limb; $\mathrm{AV}=$ atrioventricular; $\mathrm{iRBBB}=$ incomplete right bundle branch block; $\mathrm{NA}=$ not assessed.

recovery. Apart from right S1 radiculopathy sequelae, no additional muscle weakness or wasting was noted during follow-up, but CK levels stayed consistently elevated (maximal 5,500 IU/ L). Patient 3, a 65-year-old woman, developed slowly progressive proximal weakness in the lower limbs in her midthirties. Being very athletic up to that point, she noticed difficulties in walking uphill and climbing stairs. A few years later, she manifested slowly progressive proximal weakness in the upper limbs too. When she was referred for neuromuscular workup for the first time at age 43 years, she climbed stairs on her hands and feet. Clinical neurologic examination at that time confirmed proximal weakness in the lower limbs, as well as weakness of the anterior tibial muscles. Scapular winging was found. The CK level was 1,161 IU/L, and EMG revealed myopathic changes. Over the following years, the muscle weakness was slowly progressive, leading to loss of ambulation. Thorough cardiac workup revealed a first-degree AV block at night and a borderline first-degree AV block during exercise. Furthermore, no increase in the heart rate $(85 / \mathrm{min}$ during the whole test) was observed during arm ergometer testing, halted because of exhaustion at $50 \mathrm{~W}$. Both parents were deceased, and no neuromuscular or cardiac problems were reported. Of 5 siblings, 1 was deceased, and none reported muscle or cardiac symptoms. One sister agreed to be formally examined, and clinical examination was unremarkable.

Patient 4, a currently 44-year-old man, reported mild myalgia of the calves at age 39 years, 6 months after starting fibrate therapy for hypertriglyceridemia. A CK value of $8,000 \mathrm{IU} / \mathrm{L}$ was measured, and he was referred to a cardiologist. The fibrate therapy was interrupted, muscle complaints diminished, and control CK values averaged around 3,500-4,000 U/L. Initial cardiac workup, including ECG, echocardiography, and Holter monitoring, yielded normal results. The cardiologist referred the patient for neuromuscular workup. By that time, muscle complaints had resolved. A myopathic recruitment pattern was noted 
on EMG though, as well as nonspecific myopathic features on muscle biopsy. Clinical examination of 2 brothers, a 7-year-old son, and a 5-year-old daughter was unremarkable. For the parents and the 2 brothers, a normal CK value was measured. Clinically, the patient remained stable during 5 years of followup. Cardiac workup was, however, repeated and revealed a firstdegree AV block and a nocturnal second-degree Mobitz type 2 AV block. None of the patients presented with contractures, rigid spine, clinical myotonia, or myotonic discharges on EMG.

\section{Muscle imaging}

Muscle MRI studies of patients 1,2, and 3 are shown in figure 3. For patient 1, muscle MRI performed at age 28 years and repeated at age 39 years did not reveal any selective muscle involvement. For patient 2, initial CT imaging of muscle at age 20 years was normal. At age 30 years, muscle MRI showed moderate fatty replacement and atrophy of the right gastrocnemius, soleus, and biceps femoris muscles, visualizing the clinically evident residual atrophy and weakness due to the S1 radiculopathy. Additional muscle MRI studies at age 35 years confirmed these findings.

Muscle MRI of patient 3, showing the most severe skeletal muscle phenotype, revealed a pattern of selective muscle involvement with preferential affection of the posterior thigh compartment. In addition, an asymmetric moderate involvement of the left lateral vastus and relative sparing of distal leg muscles were observed.

\section{Genetic findings}

We identified 3 different homozygous variants in BVES in 3 families (table 2). Variants were absent from the ExAC control database, and in silico prediction algorithms were in favor of pathogenicity. Segregation analyses were performed with available DNA samples (figure 1). Only affected individuals harbored the variant in the homozygous state. The c.816+2$\mathrm{T}>\mathrm{C}$ variant in intron 6 of BVES affects the highly conserved canonical $\mathrm{T}$ of the splice donor site and is predicted to cause skipping of exon 6 and the loss of 56 amino acids (p.Val217 Lys272del) within the Popeye domain of BVES. Two potential cryptic splice sites could be activated alternatively: in intron 6 (c.816+46, p.Lys272fs $\left.4^{*}\right)$ or within exon 6 (c.749*, p.Arg250Argfs $20^{*}$ ). The c.262C $>\mathrm{T}$ variant (rs796206315) introduces a premature stop codon at amino acid position 88 , located in the second transmembrane domain of this short protein. According to the MutationTaster2 algorithm, ${ }^{13}$ the c. $1 \mathrm{~A}>\mathrm{G}$ variant is predicted to result in a loss of the initiating methionine (cDNA position 218) and potential activation of a downstream translation initiation site at cDNA position 354, resulting in a new reading frame with insertion of a premature stop codon at amino acid position 2 . As this potential alternative initiation site is not embedded in a strong Kozak sequence, other initiation sites might be activated at cDNA position 423 or 431 . In both cases, this would lead to an inframe deletion of 66 or 72 amino acids, respectively. Activation of different alternative start codons located more downstream could, however, also result in a shift of the reading frame with insertion of a premature stop codon.

\section{Molecular consequences at the mRNA level}

To provide direct evidence for the predicted alterations at the transcript level, Sanger sequencing and qPCR experiments were performed with mRNA extracted from muscle biopsies of patients 2, 3, and 4. PCR products of BVES cDNA

Figure 3 Muscle MRI findings in 3 patients harboring homozygous mutations in BVES

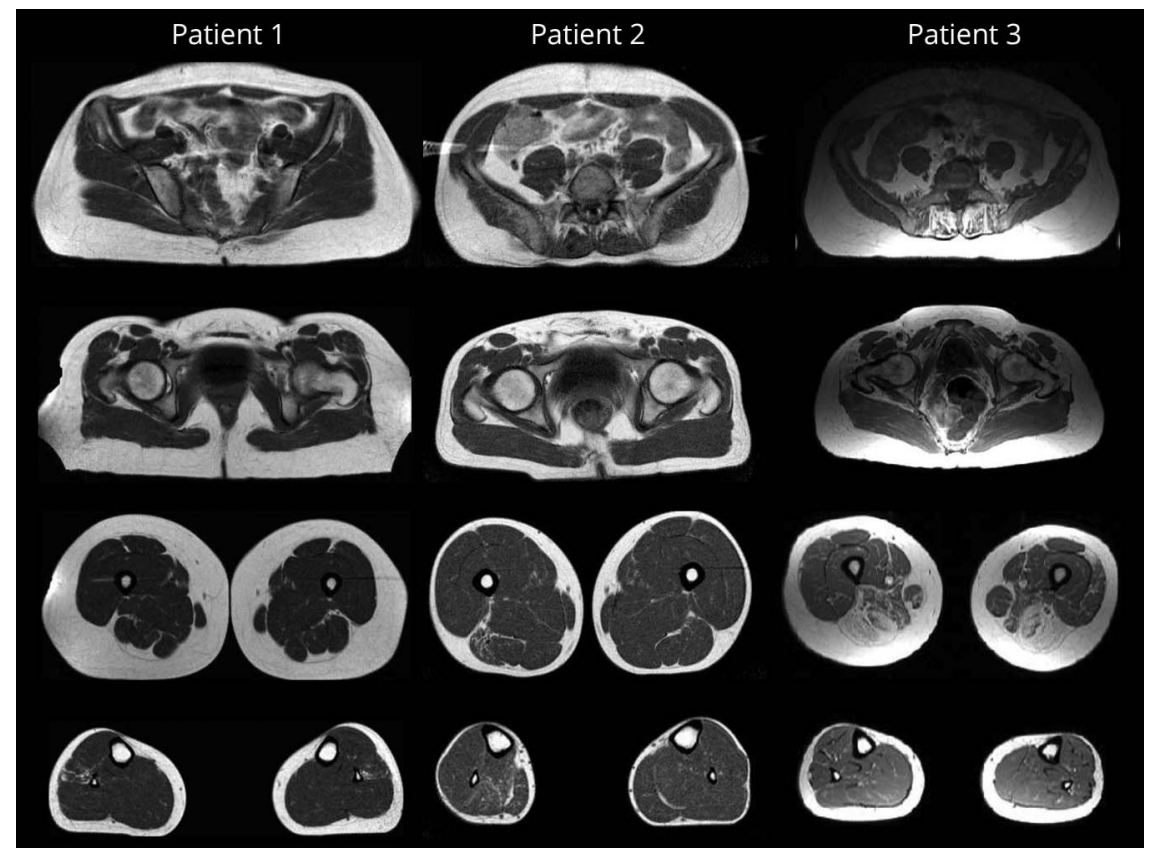

Axial T1-weighted images are shown for patients 1,2 , and 3 , performed at ages 39,35 , and 56 years, respectively. 
Table 2 BVES mutations identified in the present study

\begin{tabular}{|c|c|c|c|c|c|c|c|c|}
\hline \multirow[b]{2}{*}{ Patient } & \multicolumn{2}{|c|}{ Variant location (hg19) } & \multirow[b]{2}{*}{$\begin{array}{l}\text { Protein } \\
\text { change }\end{array}$} & \multirow[b]{2}{*}{ Genotype } & \multirow[b]{2}{*}{ Variant } & \multicolumn{2}{|c|}{ Predicted deleteriousness } & \multirow[b]{2}{*}{$\begin{array}{l}\text { ExAC allele } \\
\text { frequency }\end{array}$} \\
\hline & $\begin{array}{l}\text { Genomic (chr. } \\
\text { 6) }\end{array}$ & Coding & & & & MutationTaster2 & $\begin{array}{l}\text { CADD } \\
\text { score }\end{array}$ & \\
\hline 1 & $105564574 A>G$ & c. $816+2 T>C$ & p.? & Hom. & $\begin{array}{l}\text { Splice } \\
\text { donor }\end{array}$ & No data & No data & 0 \\
\hline 2 & $105564574 A>G$ & $c .816+2 T>C$ & p.? & Hom. & $\begin{array}{l}\text { Splice } \\
\text { donor }\end{array}$ & No data & No data & 0 \\
\hline 3 & $105577343 \mathrm{G}>\mathrm{A}$ & c. $262 C>T$ & p.Arg88Ter & Hom. & $\begin{array}{l}\text { Stop } \\
\text { gained }\end{array}$ & Disease causing & 39 & 0 \\
\hline 4 & $105581452 T>C$ & $c .1 A>G$ & p.? & Hom. & Start lost & Disease causing & 24.1 & 0 \\
\hline
\end{tabular}

Abbreviations: Hom. = homozygous; $\mathrm{CADD}=$ Combined Annotation-Dependent Depletion; start lost = variant in the start codon; ExAC = Exome Aggregation Consortium.

amplicons $\mathrm{A}, \mathrm{B}$, and $\mathrm{C}$ (figure $2 \mathrm{~A}$ ) could all be sequenced (data not shown), and all variants were confirmed at the cDNA level. Gel electrophoresis of the amplicon B encompassing exon 4 up to and including 8 revealed a shorter product for patient 2 , sized approximately 350 base pairs $(\mathrm{bp})$ instead of the expected size of $507 \mathrm{bp}$ (figure 2B). The sequencing of this fragment confirmed that exon 6 (168 bp long) was indeed spliced out. Nevertheless, fragment $C$ could be amplified for patient 2, although the forward primer is located in exon 6 . qPCR data, however, showed that these mRNA levels for amplicon $\mathrm{C}$ are close to 0 compared with the controls, indicating that the absolute level of mutant mRNA in which exon 6 is not skipped is extremely low. Furthermore, mRNA levels for amplicon A are markedly decreased as well, indicating nonsense-mediated mRNA decay (NMD) of the mutant transcript in any case. For patient 3 , qPCR for amplicons A and $C$ revealed a marked decrease in $B V E S$ mRNA relative to the controls (figure 2, C and D). For patient 4, BVES mRNA levels are similar to these in the controls.

\section{Reduction in membrane localization of POPDC1 and POPDC2}

Nonspecific myopathic features such as increased fiber size variation were noted on muscle biopsies of patients 2,3 , and 4 . In addition, for patient 2 , a few necrotic fibers were observed. Standard IHC stainings were normal.

For the previously described patients harboring the p.Ser201Phe in BVES in homozygosity, defective POPDC1 membrane trafficking was reported to result in strongly reduced membrane localization of POPDC1 and POPDC2. ${ }^{5}$ To examine POPDC1 and POPDC2 at the plasma membrane, we performed IHC stainings in patient and control muscle samples. Both POPDC1 and POPDC 2 were abundantly present at the plasma membrane of control skeletal muscle. In all patient samples, however, both POPDC1 and POPDC2 were drastically diminished at the sarcolemma (figure 4, A-D). Levels of SGCA, used as a control marker for sarcolemmal proteins, remained normal in the patient samples with similar staining patterns and intensities as for control samples. These results confirm that the predicted LOF mutations in BVES indeed lead to a loss of membrane localization and consequently the main function of POPDC1 and POPDC2 in patient muscle.

\section{Discussion}

In the present study, we identified 3 different new homozygous LOF mutations in BVES in 4 individuals from 3 families, showing early adult-onset skeletal muscle and cardiac conduction abnormalities of varying nature and severity.

The presenting symptoms vary between individuals, with patient 2 presenting with cardiac symptoms due to an AV conduction defect within the second decade and patients 1,3 and 4 with skeletal muscle symptoms or signs. Only patient 3 showed progressive proximal muscle weakness, whereas patient 1 had symptoms of exercise intolerance, and patient 4 had permanently high CK levels $(>3,500 \mathrm{IU} / \mathrm{L}$ after interruption of fibrate therapy) with transient complaints of myalgia. During follow-up, all patients appeared to have at least subclinical signs of both skeletal muscle and cardiac involvement. In patient 2 with a predominant cardiac phenotype, a chronically elevated CK level $(>1,000 \mathrm{U} / \mathrm{L})$ was noted repeatedly, as well as myopathic features on EMG and muscle biopsy. In patients 1, 3 , and 4 , initially showing a predominant skeletal muscle phenotype of variable severity, a progressive cardiac conduction disorder (PCCD) became apparent during follow-up.

Intrafamilial variability of the phenotype linked to mutations in BVES has already been shown in the originally reported consanguineous family in which a pseudodominant inheritance pattern of the p.Ser201Phe variant was described ${ }^{5}$ : the grandfather presented with an LGMD phenotype at age 40 years, complicated by a symptomatic second-degree AV block at age 59 years requiring pacemaker implantation, and the grandsons with symptomatic second-degree AV block, respectively, at age 17 years and 12 years. Cardiac conduction disorders seemed to be confined to the AV node. ${ }^{5}$ However, for patient 2, definite His-bundle involvement was shown on 
Figure 4 Reduction of POPDC1 and PODPC2 at the sarcolemma in muscle of patients harboring homozygous mutations in BVES
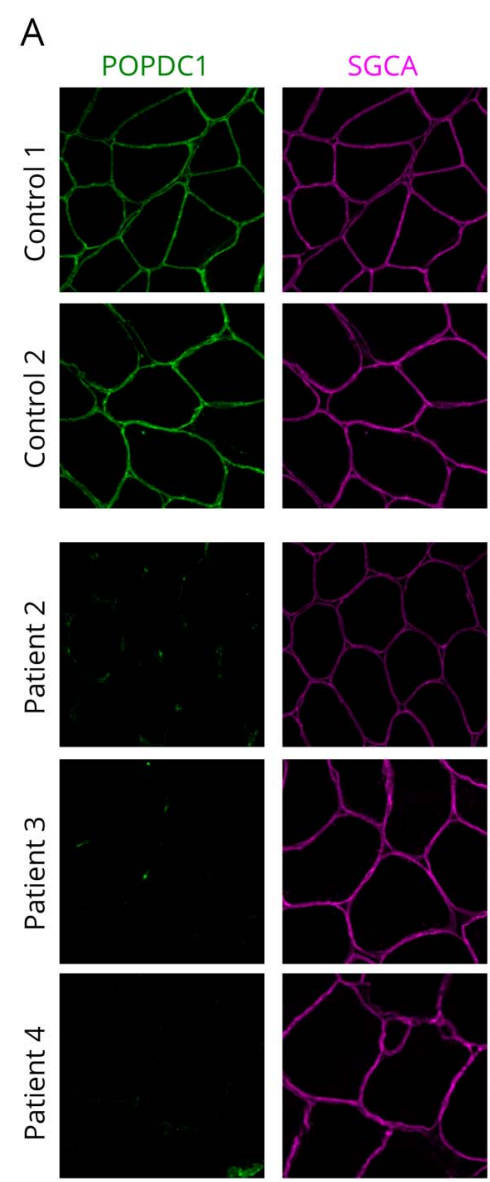

C
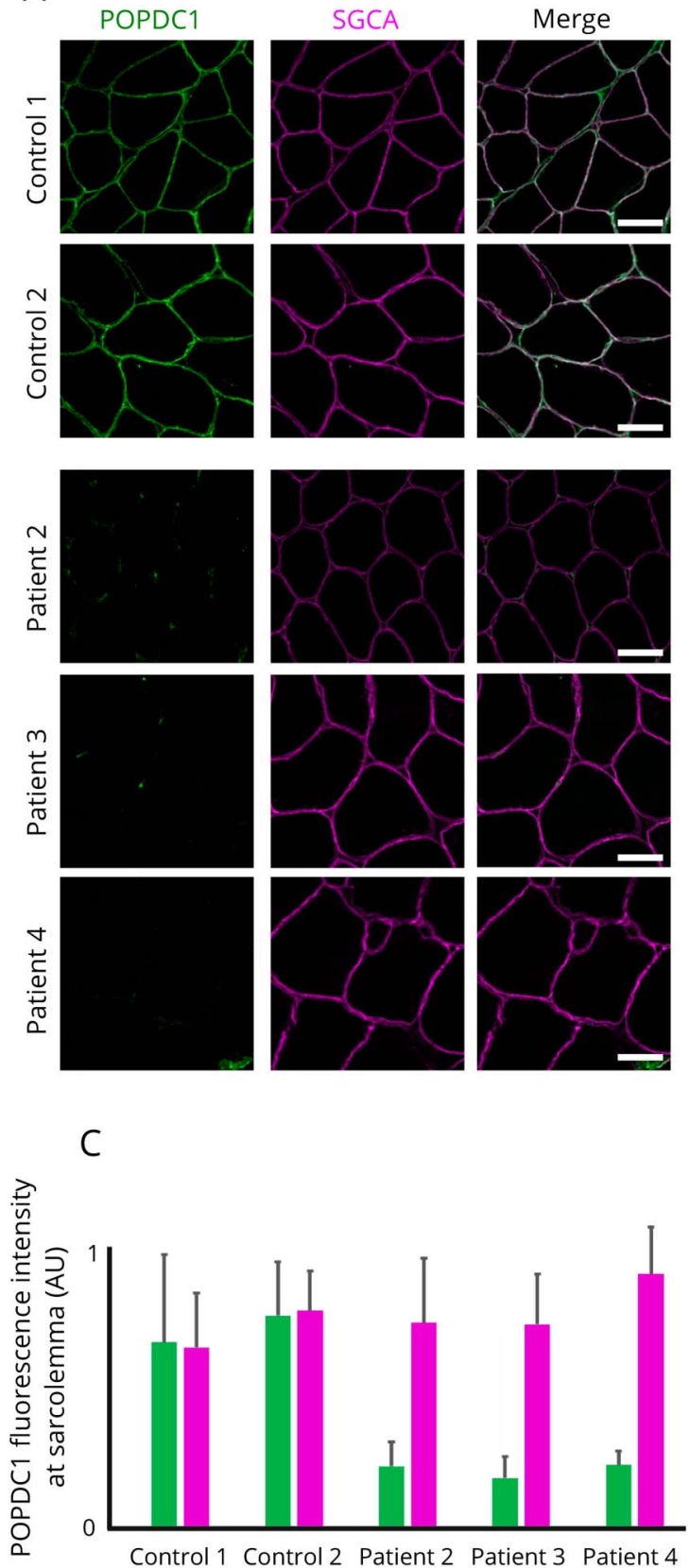

B
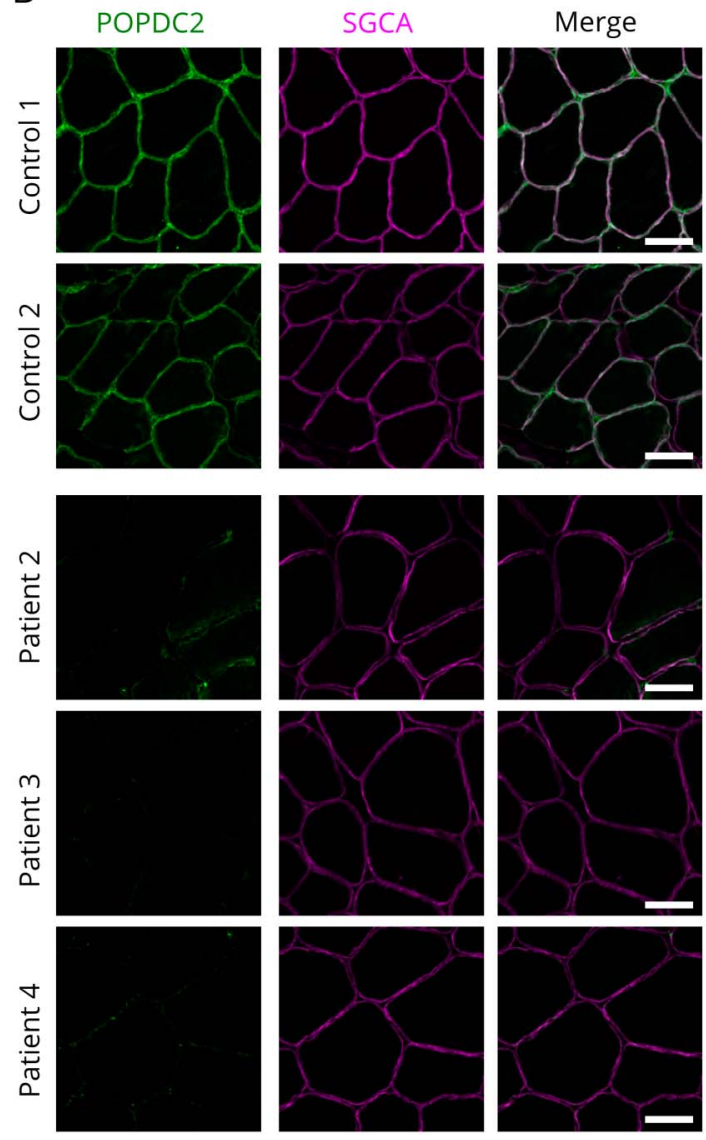

D

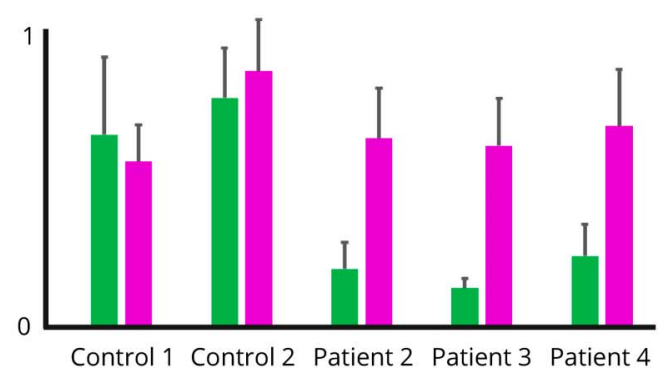

(A and B) Representative muscle sections of patients and controls immunostained for POPDC1 and POPDC2, respectively, and a-sarcoglycan (SGCA) as sarcolemmal marker. All images were acquired with identical settings and are displayed in the figure with identical intensity scaling for each channel. Scale bar = $50 \mu \mathrm{m}$. (C and D) Fluorescence intensities measured at the sarcolemma ( $n=30$ sarcolemmal segments at random positions on the section). AU = arbitrary unit.

an EPS at age 29 years. Although not fulfilling the exact criteria of chronotropic incompetence, ${ }^{17}$ the results of the arm ergometer testing in patient 3 are strongly indicative of SND. Because of lower limb weakness, only less standardized arm ergometer testing could be performed for this wheelchairusing patient. During an incremental dynamic exercise test, work load was limited to $50 \mathrm{~W}$, mainly because of weakness of the biceps muscles.
Similarly, heterogeneity was observed on muscle imaging studies. For patient 3, a pattern of selective muscle involvement was shown, with muscles of the posterior compartment of the thighs being most severely involved. Muscle MRI studies of patient 1 yielded normal results. The selective unilateral atrophy and fatty replacement of soleus, gastrocnemius, and biceps femoris muscles in patient 2 may be due to $S 1$ radiculopathy. 
As we identified additional unrelated families with a BVESrelated myopathy, we propose that this disorder should be classified as "LGMD R25 BVES-related" according to the recently published novel European Neuromuscular Centre classification of LGMDs. "LGMD2X" was excluded from the LGMD nomenclature, based on the criterion that the condition must be described in at least 2 unrelated families with affected individuals. ${ }^{18}$ All other criteria of the novel definition of an "LGMD" are fulfilled too. Each patient achieved independent walking and has an elevated CK activity. Degenerative changes on muscle imaging are clearly shown on muscle MRI of patient 3 of the current study and dystrophic changes on histology, noted for the same patient, had already been described for the eldest patient of the originally reported family too. ${ }^{5,18}$ IHC experiments revealed a pattern of consistent reduction of POPDC1 and POPDC2 at the sarcolemma, similar to the pattern described in muscle of patients harboring the homozygous p.Ser201Phe missense mutation and the popdc1 ${ }^{\mathrm{p} \text { Ser191Phe }} \mathrm{KI}$ zebrafish. ${ }^{5}$ Of note, for patient 3, harboring the homozygous p.Arg88Ter variant, no antibody targeting an epitope at the $\mathrm{N}$-terminal side of the premature stop codon was available. In addition, mRNA studies are supportive of a LOF mechanism at the mRNA level for the BVES variants in patients 2 and 3, most likely due to NMD. For patient 2, qualitative and quantitative PCR data illustrate that different splice variants are transcribed, though ultimately leading to significantly decreased BVES mRNA levels. The low level of remaining mRNA probably mainly consists of mRNA with in-frame skipping of exon 6, encoding for 56 amino acids (p.Val217_Lys272del), which are part of the Popeye domain, the crucial functional domain of the protein. For patient 4, BVES mRNA levels were similar to these in the controls. Apparently, the mutant mRNA is not targeted by $\mathrm{NMD}$, yet a nonfunctional protein is translated, which is not recognized by the anti-POPDC1 antibody, raised against the C-terminal part of the POPDC1 protein. In case of an inframe deletion of 66 or 72 amino acids at the $\mathrm{N}$-terminal end of the protein, the antibody should still recognize this truncated POPDC1 protein. This observation most likely implies that there is a shift of the reading frame, with a premature stop codon less than 55 nucleotides upstream of the last exon-exon border. In that case, NMD will be skipped and a protein with a different amino acid sequence is formed, not recognized by the anti-POPDC1 antibody. All mutations identified lead to a partial or complete loss of function of $B V E S$ through NMD or through functional changes to the POPDC1 protein.

By identifying and elaborating on LOF mutations in BVES, we expand the genetic spectrum of the disorder and provide pathomechanistic insights in the disorder. Only the p.Ser201Phe missense mutation had been previously identified in a single family. Identification of patients harboring LOF mutations in BVES could, however, be anticipated based on functional studies in homozygous zebrafish popdc1 morphants and Popdc1 null mutant mice, showing a similar phenotype compared with the popdc1 ${ }^{\text {p.Ser191Phe }} \mathrm{KI}$ zebrafish., ${ }^{5,8}$
Of interest, the Popdc1 null mutant mice revealed an agedependent stress-induced SND with chronotropic incompetence, ${ }^{8}$ a condition we also strongly suspect in patient 3. Further studies are needed to unveil the exact functional consequences of the complete loss of function of the POPDC1 protein in skeletal muscle and the heart. Crucially, POPDC2 appears to be a direct interactor of POPDC1, and aberrant trafficking of POPDC1 also impairs membrane transport of POPDC2. Heteromeric complexes might be formed, potentially explaining the secondary loss of membrane localization of POPDC2, similarly shown for patients harboring the p.Ser201Phe missense mutation. ${ }^{5}$ This appears to be pathomechanistically relevant, as popdc2 zebrafish morphants show a severe muscular dystrophy phenotype and cardiac abnormalities too. ${ }^{19}$

Our findings stress the importance of a thorough cardiac workup in (unsolved) LGMD patients. Cardiac workup is often focused on structural cardiac evaluation, ${ }^{3}$ but as in myotonic dystrophy, ${ }^{2}$ extensive and repeated screening for arrhythmias in the absence of structural heart disease is definitely relevant in case of a BVES-related myopathy.

Furthermore, this study highlights the diagnostic difficulties that can be faced in case of pauci- or asymptomatic hyperCKemia. ${ }^{20}$ We note chronically elevated CK values ( $>3$ times the upper limit of normal) in all patients. In the absence of marked dystrophic features on muscle biopsy, this may be an indication of membrane instability linked to the interaction of POPDC1 with dystrophin, dysferlin, and caveolin $3{ }^{6,21}$ In addition, ultrastructural analysis of muscle of the grandfather of the p.Ser201Phe family revealed membrane discontinuities. ${ }^{5}$ When further neuromuscular workup is advised in this clinical setting according to guidelines, ${ }^{20,22}$ cardiac screening could be relevant too, regardless of the results of the neuromuscular workup. The other way around, our findings suggest that $B V E S$ should be included in a candidate gene list for PCCDs presenting as primary electrical disease. The search for culprit genes has long been complicated by the fact that most cardiac conduction disorders are sporadic, as they are highly prevalent and usually associated with diverse (acquired) structural heart disease. Channelopathies are evidently the predominant hereditary entities associated with PCCD. ${ }^{4,23}$ Furthermore, a short clinical neuromuscular evaluation, including CK measurement, could be of value when a hereditary PCCD is suspected.

Identification of LOF mutations in BVES underlines by extension the role of the POPDC protein family in striated muscle physiology and disease. ${ }^{6}$ We present 4 individuals from 3 families harboring homozygous LOF variants in BVES, showing early adult-onset skeletal muscle and cardiac conduction abnormalities of varying nature and severity. Overall, this recessive disorder linked to mutations in BVES appears to have a low prevalence, but is probably underdiagnosed because of its striking phenotypic variability and often subtle yet clinically relevant manifestations. 


\section{Acknowledgment}

The authors thank the patients and families for their cooperation and contributions; Sophie D'hose, technician, Laboratory for Neuropathology, Division of Neurology, Ghent University Hospital, for laboratory assistance; and Ursula Herbort-Brand, technician, Imperial College London, for laboratory assistance.

\section{Study funding}

The study received financial support from Sanofi Genzyme, Ultragenyx, LGMD2I Research Fund, Samantha J. Brazzo Foundation, LGMD2D Foundation, Kurt+Peter Foundation, Muscular Dystrophy UK and Coalition to Cure Calpain 3, the Association Belge contre les Maladies Neuromusculaire (ABMM) - Aide à la Recherche ASBL, the Institut National de la Santé et de la Recherche Médicale, the Sorbonne Université- Faculté de Médecine, the Association Française contre les Myopathies and France Génomique (Myocapture Project), National Research Agency, and Investment for the Future (Grant No. ANR-10-INBS-09). J.B. is supported by a Senior Clinical Researcher mandate of the Research Fund-Flanders (FWO). T.B. is supported by grants from the British Heart Foundation (PG/14/46/30911 and PG/ $14 / 83 / 31128$ ) and the Magdi Yacoub Institute.

\section{Disclosure}

W. De Ridder, I. Nelson, and B. Asselbergh report no disclosures. B. De Paepe has served on the editorial boards of Clinical Medicine and Diagnostics and ISRN Pathology and has received foundation/society research support from the Association Belge contre les Maladies neuromusculaires. M. Beuvin, R. Ben Yaou, C. Masson, and A. Boland report no disclosures. J.-F. Deleuze has served on the editorial board of Human Genetics; holds patents in genetic diagnostics; and has received government research support from the French National Research Agency. T. Maisonobe, B. Eymard, and S. Symoens report no disclosures. R. Schindler has been employed by Domainex Ltd. T. Brand has served on the editorial boards of the Journal of Cardiovascular Development and Disease, Cellular Signaling, and PLoS One and has received foundation/society support from the British Heart Foundation and AFM Telethon. K. Johnson and A. Töpf report no disclosures. V. Straub has served on the advisory boards of Audentes Therapeutics, Summit Therapeutics, Biogen, Exonics Therapeutics, Sanofi Genzyme, Sarepta Therapeutics, Wave Therapeutics, and Roche; has received travel funding or speaker honoraria from Sanofi Genzyme; has served on the editorial boards of Neuromuscular Disorders and Journal of Neuromuscular Diseases; has consulted for Bayer, Wave Therapeutics, and UCB; has received commercial research support from Sanofi Genzyme; has received government funding support from the European Commission and the UK Medical Research Council; and has received foundation/society research support from the Parent Project Muscular Dystrophy, Association Francaise contre les Myopathies, the LGMD2I Research Fund, Muscular Dystrophy UK, and Duchenne-UK. P. De Jonghe reports no disclosures.
J.L. De Bleecker has served on the advisory boards of Sanofi Genzyme, Pfizer, and CSL Behring and has received travel funding or speaker honoraria from Sanofi Genzyme and CSL Behring. G. Bonne has served on the editorial boards of the Journal of Neuromuscular Disease and Neuromuscular Disorders; has received academic research support from ANR-BMBF; and has received foundation/society research support from Association Institut de Myologie, GIS Maladies Rare "Plateforme Mutations," and CURE-CMD Translational Award. J. Baets reports no disclosures. Full disclosure form information provided by the authors is available with the full text of this article at Neurology. org/NG.

\section{Publication history}

Received by Neurology: Genetics November 21, 2018. Accepted in final form February 12, 2019.

Appendix Author contributions

\begin{tabular}{|c|c|c|c|}
\hline Name & Location & Role & Contribution \\
\hline $\begin{array}{l}\text { Willem De } \\
\text { Ridder, MD }\end{array}$ & $\begin{array}{l}\text { University of } \\
\text { Antwerp, } \\
\text { Antwerp, } \\
\text { Belgium }\end{array}$ & Author & $\begin{array}{l}\text { Acquisition and } \\
\text { interpretation of patient, } \\
\text { imaging, and } \\
\text { histopathology data, } \\
\text { analysis of genetic data, } \\
\text { and manuscript writing }\end{array}$ \\
\hline $\begin{array}{l}\text { Isabelle } \\
\text { Nelson, PhD }\end{array}$ & $\begin{array}{l}\text { Institute of } \\
\text { Myology, G.H. } \\
\text { Pitié-Salpêtrière } \\
\text { Paris, France }\end{array}$ & Author & $\begin{array}{l}\text { Acquisition and } \\
\text { interpretation of genetic } \\
\text { data and manuscript } \\
\text { writing }\end{array}$ \\
\hline $\begin{array}{l}\text { Bob } \\
\text { Asselbergh, } \\
\text { PhD }\end{array}$ & $\begin{array}{l}\text { University of } \\
\text { Antwerp, } \\
\text { Antwerp, } \\
\text { Belgium }\end{array}$ & Author & $\begin{array}{l}\text { Interpretation of } \\
\text { histopathology data }\end{array}$ \\
\hline $\begin{array}{l}\text { Boel De } \\
\text { Paepe, PhD }\end{array}$ & $\begin{array}{l}\text { Ghent University } \\
\text { Hospital, Ghent, } \\
\text { Belgium }\end{array}$ & Author & $\begin{array}{l}\text { Interpretation of } \\
\text { histopathology data }\end{array}$ \\
\hline $\begin{array}{l}\text { Maud Beuvin, } \\
\text { MSc }\end{array}$ & $\begin{array}{l}\text { Institute of } \\
\text { Myology, G.H. } \\
\text { Pitié-Salpêtrière } \\
\text { Paris F-75013, } \\
\text { France }\end{array}$ & Author & $\begin{array}{l}\text { Acquisition and } \\
\text { interpretation of protein } \\
\text { expression data } \\
\text { (immunohistopathology) }\end{array}$ \\
\hline $\begin{array}{l}\text { Rabah Ben } \\
\text { Yaou, MD }\end{array}$ & $\begin{array}{l}\text { Institute of } \\
\text { Myology, G.H. } \\
\text { Pitié-Salpêtrière } \\
\text { Paris F-75013, } \\
\text { France }\end{array}$ & Author & $\begin{array}{l}\text { Acquisition and } \\
\text { interpretation of patient, } \\
\text { imaging, and } \\
\text { histopathology data and } \\
\text { manuscript writing }\end{array}$ \\
\hline $\begin{array}{l}\text { Cécile } \\
\text { Masson, MSc }\end{array}$ & $\begin{array}{l}\text { University Paris } \\
\text { Descartes, F- } \\
\text { 75015, Paris, } \\
\text { France }\end{array}$ & Author & $\begin{array}{l}\text { Interpretation of genetic } \\
\text { data }\end{array}$ \\
\hline $\begin{array}{l}\text { Anne Boland, } \\
\text { PhD }\end{array}$ & $\begin{array}{l}\text { Université Paris- } \\
\text { Saclay, F-91057, } \\
\text { Evry, France }\end{array}$ & Author & $\begin{array}{l}\text { Acquisition of genetic } \\
\text { data }\end{array}$ \\
\hline $\begin{array}{l}\text { JeanFrançois, } \\
\text { Deleuze, PhD }\end{array}$ & $\begin{array}{l}\text { Université Paris- } \\
\text { Saclay, F-91057, } \\
\text { Evry, France }\end{array}$ & Author & $\begin{array}{l}\text { Acquisition of genetic } \\
\text { data }\end{array}$ \\
\hline $\begin{array}{l}\text { Thierry } \\
\text { Maisonobe, } \\
\text { MD }\end{array}$ & $\begin{array}{l}\text { Université Paris- } \\
\text { Saclay, F-91057, } \\
\text { Evry, France }\end{array}$ & Author & $\begin{array}{l}\text { Acquisition and } \\
\text { interpretation of } \\
\text { histopathology data }\end{array}$ \\
\hline
\end{tabular}


Appendix (continued)

\begin{tabular}{|c|c|c|c|}
\hline Name & Location & Role & Contribution \\
\hline $\begin{array}{l}\text { Bruno } \\
\text { Eymard, MD, } \\
\text { PhD }\end{array}$ & $\begin{array}{l}\text { G.H. Pitié- } \\
\text { Salpêtrière, F- } \\
\text { 75013, Paris, } \\
\text { France }\end{array}$ & Author & $\begin{array}{l}\text { Acquisition and } \\
\text { interpretation of patient } \\
\text { data }\end{array}$ \\
\hline $\begin{array}{l}\text { Sofie } \\
\text { Symoens, } \\
\text { PhD }\end{array}$ & $\begin{array}{l}\text { Ghent University } \\
\text { Hospital, Ghent, } \\
\text { Belgium }\end{array}$ & Author & Analysis of genetic data \\
\hline $\begin{array}{l}\text { Roland } \\
\text { Schindler, } \\
\text { PhD }\end{array}$ & $\begin{array}{l}\text { Imperial College } \\
\text { London, London, } \\
\text { W12 0NN, } \\
\text { United Kingdom }\end{array}$ & Author & $\begin{array}{l}\text { Critical revision of the } \\
\text { manuscript for } \\
\text { important intellectual } \\
\text { content }\end{array}$ \\
\hline $\begin{array}{l}\text { Thomas } \\
\text { Brand, PhD }\end{array}$ & $\begin{array}{l}\text { Imperial College } \\
\text { London, London, } \\
\text { W12 0NN, } \\
\text { United Kingdom }\end{array}$ & Author & $\begin{array}{l}\text { Critical revision of the } \\
\text { manuscript for } \\
\text { important intellectual } \\
\text { content }\end{array}$ \\
\hline $\begin{array}{l}\text { Katherine } \\
\text { Johnson, PhD }\end{array}$ & $\begin{array}{l}\text { Newcastle } \\
\text { University, } \\
\text { Newcastle upon } \\
\text { Tyne, United } \\
\text { Kingdom }\end{array}$ & Author & Analysis of genetic data \\
\hline Ana Töpf, PhD & $\begin{array}{l}\text { Newcastle } \\
\text { University, } \\
\text { Newcastle upon } \\
\text { Tyne, United } \\
\text { Kingdom }\end{array}$ & Author & Analysis of genetic data \\
\hline $\begin{array}{l}\text { Volker } \\
\text { Straub, MD, } \\
\text { PhD }\end{array}$ & $\begin{array}{l}\text { Newcastle } \\
\text { University, } \\
\text { Newcastle upon } \\
\text { Tyne, United } \\
\text { Kingdom }\end{array}$ & Author & $\begin{array}{l}\text { Critical revision of the } \\
\text { manuscript for } \\
\text { important intellectual } \\
\text { content }\end{array}$ \\
\hline $\begin{array}{l}\text { Peter De } \\
\text { Jonghe, MD, } \\
\text { PhD }\end{array}$ & $\begin{array}{l}\text { University of } \\
\text { Antwerp, } \\
\text { Antwerp, } \\
\text { Belgium }\end{array}$ & Author & $\begin{array}{l}\text { Acquisition of patient } \\
\text { and imaging data and } \\
\text { critical revision of the } \\
\text { manuscript for } \\
\text { important intellectual } \\
\text { content }\end{array}$ \\
\hline $\begin{array}{l}\text { Jan L. De } \\
\text { Bleecker, MD, } \\
\text { PhD }\end{array}$ & $\begin{array}{l}\text { Ghent University } \\
\text { Hospital, Ghent, } \\
\text { Belgium }\end{array}$ & Author & $\begin{array}{l}\text { Acquisition and } \\
\text { interpretation of patient, } \\
\text { imaging, and } \\
\text { histopathology data }\end{array}$ \\
\hline $\begin{array}{l}\text { Gisèle Bonne, } \\
\text { PhD }\end{array}$ & $\begin{array}{l}\text { Institute of } \\
\text { Myology, G.H. } \\
\text { Pitié-, Salpêtrière } \\
\text { Paris F-75013, } \\
\text { France }\end{array}$ & Author & $\begin{array}{l}\text { Study supervision, study } \\
\text { concept and design, and } \\
\text { critical revision of the } \\
\text { manuscript for } \\
\text { important intellectual } \\
\text { content }\end{array}$ \\
\hline $\begin{array}{l}\text { Jonathan } \\
\text { Baets, MD, } \\
\text { PhD }\end{array}$ & $\begin{array}{l}\text { University of } \\
\text { Antwerp, } \\
\text { Antwerp, } \\
\text { Belgium }\end{array}$ & Author & $\begin{array}{l}\text { Acquisition and } \\
\text { interpretation of patient, } \\
\text { imaging and } \\
\text { histopathology data, } \\
\text { study supervision, study } \\
\text { concept and design, and } \\
\text { critical revision of the } \\
\text { manuscript for } \\
\text { important intellectual } \\
\text { content }\end{array}$ \\
\hline
\end{tabular}

\section{References}

1. Vissing J. Limb girdle muscular dystrophies: classification, clinical spectrum and emerging therapies. Curr Opin Neurol 2016;29:635-641.

2. Silvestri NJ, Ismail H, Zimetbaum P, Raynor EM. Cardiac involvement in the muscular dystrophies. Muscle Nerve 2018;57:707-715.

3. Narayanaswami $P$, Weiss $M$, Selcen $D$, et al. Evidence-based guideline summary: diagnosis and treatment of limb-girdle and distal dystrophies: report of the guideline development subcommittee of the American Academy of Neurology and the practice issues review panel of the American Association of Neuromuscular \& Electrodiagnostic Medicine. Neurology 2014;83:1453-1463.

4. Rezazadeh S, Duff HJ. Genetic determinants of hereditary bradyarrhythmias: a contemporary review of a diverse group of disorders. Can J Cardiol 2017;33: $758-767$.

5. Schindler RF, Scotton C, Zhang J, et al. POPDC1(S201F) causes muscular dystrophy and arrhythmia by affecting protein trafficking. J Clin Invest 2016;126: 239-253.

6. Brand T, Schindler R. New kids on the block: the Popeye domain containing (POPDC) protein family acting as a novel class of cAMP effector proteins in striated muscle. Cell Signal 2017;40:156-165.

7. Andree B, Fleige A, Arnold HH, Brand T. Mouse Pop1 is required for muscle regeneration in adult skeletal muscle. Mol Cell Biol 2002;22:1504-1512.

8. Froese A, Breher SS, Waldeyer C, et al. Popeye domain containing proteins are essential for stress-mediated modulation of cardiac pacemaking in mice. J Clin Invest 2012;122:1119-1130.

9. Mercuri E, Pichiecchio A, Allsop J, Messina S, Pane M, Muntoni F. Muscle MRI in inherited neuromuscular disorders: past, present, and future. J Magn Reson Imaging 2007;25:433-440.

10. Gordon CT, Petit F, Kroisel PM, et al Mutations in endothelin 1 cause recessive auriculocondylar syndrome and dominant isolated question-mark ears. Am J Hum Genet 2013;93:1118-1125.

11. Peric S, Glumac JN, Topf A, et al. A novel recessive TTN founder variant is a common cause of distal myopathy in the Serbian population. Eur J Hum Genet : EJHG 2017; 25:572-581.

12. Lek M, Karczewski KJ, Minikel EV, et al. Analysis of protein-coding genetic variation in 60,706 humans. Nature 2016;536:285-291.

13. Schwarz JM, Cooper DN, Schuelke M, Seelow D. MutationTaster2: mutation prediction for the deep-sequencing age. Nat Methods 2014;11:361-362.

14. Kircher M, Witten DM, Jain P, O’Roak BJ, Cooper GM, Shendure J. A general framework for estimating the relative pathogenicity of human genetic variants. Nat Genet 2014;46:310-315.

15. Schindelin J, Arganda-Carreras I, Frise E, et al. Fiji: an open-source platform for biological-image analysis. Nat Methods 2012;9:676-682.

16. Rueden CT, Schindelin J, Hiner MC, et al. ImageJ2: ImageJ for the next generation of scientific image data. BMC Bioinformatics 2017;18:529.

17. Brubaker PH, Kitzman DW. Chronotropic incompetence: causes, consequences, and management. Circulation 2011;123:1010-1020.

18. Straub V, Murphy A, Udd B. 229th ENMC international workshop: limb girdle muscular dystrophies - nomenclature and reformed classification Naarden, The Netherlands, 17-19 March 2017. Neuromuscul Disord 2018;28: 702-710.

19. Kirchmaier BC, Poon KL, Schwerte T, et al. The Popeye domain containing 2 (popdc2) gene in zebrafish is required for heart and skeletal muscle development. Dev Biol 2012;363:438-450.

20. Kyriakides T, Angelini C, Schaefer J, et al. EFNS guidelines on the diagnostic approach to pauci- or asymptomatic hyperCKemia. Eur J Neurol 2010;17: $767-773$.

21. Alcalay Y, Hochhauser E, Kliminski V, et al. Popeye domain containing 1 (Popdc1/ Bves) is a caveolae-associated protein involved in ischemia tolerance. PLoS One 2013; 8:e71100.

22. Silvestri NJ, Wolfe GI. Asymptomatic/pauci-symptomatic creatine kinase elevations (hyperckemia). Muscle \& nerve 2013;47:805-815.

23. Baruteau AE, Probst V, Abriel H. Inherited progressive cardiac conduction disorders. Curr Opin Cardiol 2015;30:33-39. 


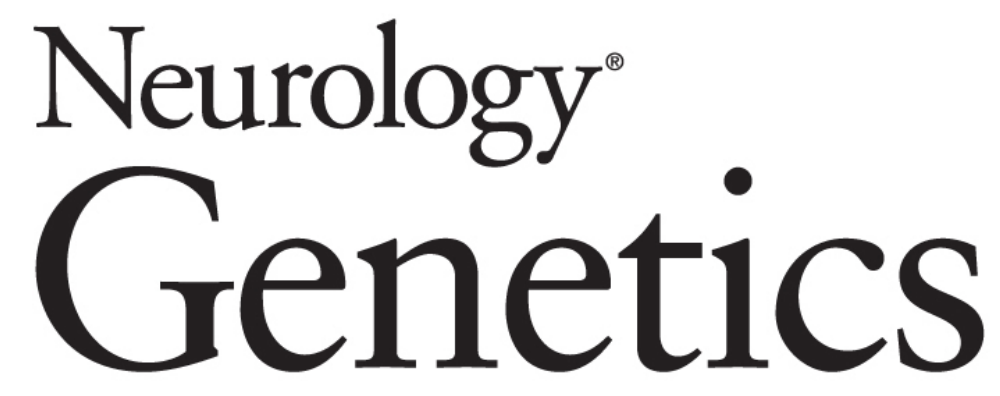

Muscular dystrophy with arrhythmia caused by loss-of-function mutations in BVES Willem De Ridder, Isabelle Nelson, Bob Asselbergh, et al. Neurol Genet 2019;5;

DOI 10.1212/NXG.0000000000000321

This information is current as of April 1, 2019

\section{Updated Information \& Services}

References

Citations

Subspecialty Collections

Permissions \& Licensing

Reprints including high resolution figures, can be found at: http://ng.neurology.org/content/5/2/e321.full.html

This article cites 23 articles, 2 of which you can access for free at: http://ng.neurology.org/content/5/2/e321.full.html\#\#ref-list-1

This article has been cited by 4 HighWire-hosted articles: http://ng.neurology.org/content/5/2/e321.full.html\#\#otherarticles

This article, along with others on similar topics, appears in the following collection(s):

\section{All Genetics}

http://ng.neurology.org//cgi/collection/all_genetics

Cardiac; see Cerebrovascular Disease/Cardiac

http://ng.neurology.org//cgi/collection/cardiac_see_cerebrovascular_di sease-cardiac

Muscle disease

http://ng.neurology.org//cgi/collection/muscle_disease

Information about reproducing this article in parts (figures,tables) or in its entirety can be found online at:

http://ng.neurology.org/misc/about.xhtml\#permissions

Information about ordering reprints can be found online: http://ng.neurology.org/misc/addir.xhtml\#reprintsus

Neurol Genet is an official journal of the American Academy of Neurology. Published since April 2015, it is an open-access, online-only, continuous publication journal. Copyright Copyright @ 2019 The Author(s). Published by Wolters Kluwer Health, Inc. on behalf of the American Academy of Neurology.. All rights reserved. Online ISSN: 2376-7839.

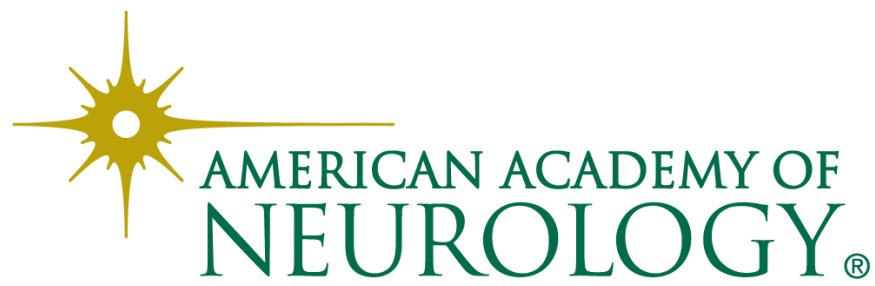

